\section{Efficacy of Chlorine in Controlling Five Common Plant Pathogens}

\author{
Diane Feliciano Cayanan, Ping Zhang, Weizhong Liu, \\ Mike Dixon, and Youbin Zheng ${ }^{1}$ \\ Controlled Environment Systems Research Facility, Department of \\ Environmental Biology, University of Guelph, 50 Stone Road West, \\ Guelph, Ontario, N1G 2W1, Canada
} Additional index words. Phytophthora infestans, Phytophthora cactorum, Pythium aphani-
dermatum, Fusarium oxysporum, Rhizoctonia solani

\begin{abstract}
Recycled irrigation water is one of the major sources of inoculum and may spread plant pathogens throughout the nursery or greenhouse operation. Chlorination is the most economical method of disinfecting water and has been adopted by some North American commercial growers. However, chlorine has not been assessed as a disinfectant for the common plant pathogens Phytophthora infestans, Phytophthora cactorum, Pythium aphanidermatum, Fusarium oxysporum, and Rhizoctonia solani. These pathogens were exposed to five different initially free chlorine solution concentrations ranging from 0.3 to $14 \mathrm{mg} \cdot \mathrm{L}^{-1}$ in combination with five contact times of $0.5,1.5,3,6$, and $10 \mathrm{~min}$ to determine the free chlorine threshold and critical contact time required to kill each pathogen. Results indicated that the free chlorine threshold and critical contact time for control of $P$. infestans, $P$. cactorum, $P$. aphanidermatum, $F$. oxysporum, and $R$. solani were $1,0.3,2$, 14 , and $12 \mathrm{mg} \cdot \mathrm{L}^{-1}$ for $3,6,3,6$, and $10 \mathrm{~min}$, respectively.
\end{abstract}

With environmental regulations focused on water quality and reducing pollution discharge associated with nutrient and pesticide applications, recycling irrigation water has been increasingly adopted by commercial nursery and greenhouse growers (Bush, 2002; Bush et al., 2003; Ehret et al., 2001; Hong and Moorman, 2005; Hong et al., 2003; Richard et al., 2006; Ryu and Beuchat, 2005; Schnitzler, 2003; Schoene et al., 2006; Skimina, 1992). Recycling involves collecting excess irrigation water and leachate into a reservoir until the water is needed again for irrigation. However, the risk of spreading plant pathogens found in recycled irrigation water is a deterrent for many operations (Bush, 2002; Bush et al., 2003; Ehret et al., 2001; Hong and Moorman, 2005; Newman, 2004; Poncet et al., 2001). Richard et al. (2006) conducted a survey on the status of irrigation water recycling in Ontario, Canada, and found that $33 \%$ of growers who use recirculating systems list disease control as a major problem. Recycling irrigation solutions have both environmental and ecological benefits (Schnitzler, 2003) but if not disinfected, it can result in serious disease epidemics and crop losses (Hong et al., 2003).

Plant pathogens detected in water supplies and irrigation systems include fungi,

Received for publication 27 May 2008. Accepted for publication 24 Sept. 2008.

This project was funded by the Canada-Ontario Research and Development Program through Flowers Canada (Ontario) and Landscape Ontario. We thank Harold Platt, Ian MacDonald, Tom Graham, Audra Stechyshyn-Nagasawa, Matt Hannaburg, Jennifer Llewellyn, and Diana Mooij for their technical support.

${ }^{1}$ To whom reprint requests should be addressed; e-mail yzheng@uoguelph.ca. fungal-like organisms, nematodes, viruses, and bacteria (Faulkner and Bolander, 1966; Hong et al., 2003; Koenig, 1986; Schnitzler, 2003; Thomson and Allen, 1974). Hong and Moorman (2005) reported that 17 Phytophthora spp., 26 Pythium spp., 27 genera of fungi, eight species of bacteria, 10 viruses, and 13 species of plant parasitic nematodes have been detected from ponds, rivers, canals, streams, lakes, runoff water, watersheds, reservoirs, wells, holding tanks, effluents, ebb and flow systems, recirculating systems, and hydroponic systems. The most destructive pathogens are Pythiaceae fungallike organisms such as Pythium and Phytophthora followed by viruses, bacteria, and nematodes (Schnitzler, 2003).

Traditionally, growers rely on preventive fungicides for management of diseases in greenhouses and nurseries such as fosetyl$\mathrm{Al}$ and metalaxyl to control phytophthora and pythium diseases (Ben-Yephet and Nelson, 1999; Kuhajek et al., 2003); however, there are already metalaxy-resistant Phytophthora and Pythium spp. such as Pythium aphanidermatum (Sanders et al., 1985), Phytophthora infestans, Phytophthora capsici, Phytophthora nicotianae, and Phytophthora citricola (Kuhajek et al., 2003). These fungifurther development of fungicide resistance (Hong et al., 2003; Sanders et al., 1985). There is a concern regarding pesticide pollution in the environment and contamination of drinking water. There are areas in Europe with raw water that contain relatively high concentrations of pesticides, which has increased public concern regarding pesticide contamination of drinking water (Griffini et al., 1999). Even with fungicide use, there is no completely effective treatment of $R h i$ zoctonia solani (Johnson and Leach, 2006) cides are expensive and there is concern for and Fusarium oxysporum (Reuveni et al., 2002).

Several disinfection techniques have been studied for their efficacy in minimize the spread of plant pathogens in recycling systems, which include slow sandbed filtration, ultraviolet irradiation (Ehret et al., 2001; Hong et al., 2003; Igura et al., 2004; Schnitzler, 2003), heating (Lin et al., 1998), ozonation, nonionic surfactants, and chlorination (Ehret et al., 2001; Hong et al., 2003).

Chlorination is an economical method of disinfecting water and remains the primary method of treating municipal water (Havard, 2003; Hong et al., 2003). Chlorination technology has already been adopted by some growers to disinfect their irrigation systems and water. However, specific recommendations for use in nursery or greenhouse irrigation to control the spread of plant pathogens have not been fully assessed (Datnoff et al., 1987; Hong et al., 2003; Johnson et al., 1997; Le Dantec et al., 2002; Taylor et al., 2000; White, 1992).

Some research in assessing chlorine's efficacy in killing several pathogens has shown that sensitivity to chlorine is pathogen-dependent. Taylor et al. (2000) reported that to inactivate $99.9 \%$ of five different Mycobacterium avium strains, chlorine concentrations ranged from 51 to $204 \mathrm{mg} \cdot \mathrm{L}^{-1}$. Erwinia carotovora subsp. Zeae Sabet was killed at $1 \mathrm{mg} \cdot \mathrm{L}^{-1}$ of chlorine (Thompson, 1965), and Hong et al. (2003) reported that zoospores of Phytophthora nicotianae, $P$. capsici, P. cinnamomi, P. citricola, $P$. citrophthora, $P$. cryptogea, and $P$. megasperma were killed with free chlorine ranging from 0.25 to $2 \mathrm{mg} \cdot \mathrm{L}^{-1}$; however, there are no studies for control of $P$. infestans and $P$. cactorum. There are also no studies regarding chlorine's efficacy in controlling Pythium aphanidermatum, $F$. oxysporum, and $R$. solani. Literature has indicated that sensitivity to chlorine varies with contact time (Copes et al., 2001; Datnoff et al., 1987; Johnson et al., 1997; Segall, 1968).

Chlorine is divided into three types of chlorine residual: 1) free chlorine, which is composed of dissolved chlorine gas $\left(\mathrm{Cl}_{2}\right)$, hypochlorous acid $(\mathrm{HOCl})$, and hypochlorite ion $\left(\mathrm{OCl}^{-}\right)$in water after chlorination; 2) combined chlorine, which is chlorine combined with ammonia $\left(\mathrm{NH}_{3}\right)$ or organic nitrogen in water as chloramines or other chloroderivatives (Hong et al., 2003); and 3 ) total chlorine, which is the sum of the free and combined chlorine in water (Hong et al., 2003; Morganti, 2002; Rutala and Weber, 1997; White, 1992). Combined chlorine is more stable but is less biocidal than free chlorine. For this reason, we used free chlorine for our research.

The free chlorine threshold and critical contact time are defined in this study as the lowest free chlorine concentration and the shortest contact time for that chlorine threshold at which there was no longer detection of any colony-forming units (cfu). Using this definition, the objective of this study was to determine the free chlorine threshold and 
critical contact time that would kill the sporangia of Phytophthora infestans, zoospores of Phytophthora cactorum and Pythium aphanidermatum, conidia of Fusarium oxysporum, and mycelia of Rhizoctonia solani.

\section{Materials and Methods}

Propagule preparation. A pure isolate of Phytophthora infestans P1661 was obtained from Dr. Harold Platt at Agriculture and Agri-Food Canada (Charlottetown, P.E.I., Canada) and incubated on rye agar at $18{ }^{\circ} \mathrm{C}$ with $12 \mathrm{~h}$ of light and $12 \mathrm{~h}$ of dark to produce sporangia. After $13 \mathrm{~d}, 5 \mathrm{~mL}$ of sterile double distilled water (SDDW) was added to the $P$. infestans growing on rye agar and the agar surface was gently rubbed with a cell scraper to dislodge the mycelia. The SDDW with the dislodged mycelia was collected in a sterile beaker and incubated at 9 to $10^{\circ} \mathrm{C}$ for $1 \mathrm{~h}$ and then at $20^{\circ} \mathrm{C}$ for another $1 \mathrm{~h}$ to release the sporangia. The sporangia suspension was filtered through two layers of sterile cheesecloth to obtain a suspension free of hyphal fragments. The sporangia concentration was determined with a hemacytometer and diluted to $\approx 10^{5}$ sporangia $/ \mathrm{mL}$. After each chlorine treatment (described subsequently), surviving sporangia were incubated on rye agar at $18{ }^{\circ} \mathrm{C}$ with $12 \mathrm{~h}$ of light and $12 \mathrm{~h}$ of dark for $4 \mathrm{~d}$.

Rye agar was prepared as follows. Two liters of SDDW and $120 \mathrm{~g}$ of organic rye kernels (Grain Process Enterprises Ltd., Scarborough, Ontario, Canada) were boiled until only $1 \mathrm{~L}$ remained. Rye kernels were removed by straining the boiled rye water through two layers of cheesecloth. The rye water was centrifuged at $650 g_{\mathrm{n}}$ for $5 \mathrm{~min}$ with a Du Pont Instrument Sorvall RC-JB Refrigerated Superspeed Centrifuge and a Sorvall GSA Rotor (Mandel Scientific Co. Inc., Guelph, Ontario, Canada). The supernatant was collected and SDDW was added to the supernatant to make up a final volume of 2 L. Two grams of dextrose (Fisher Scientific, Ottawa, Ontario, Canada) and $27 \mathrm{~g}$ of granulated agar (Fisher Scientific) were added to the rye water. The agar was melted and then sterilized at $121{ }^{\circ} \mathrm{C}$ for $20 \mathrm{~min}$.

A pure isolate of Phytophthora cactorum was obtained from Audra StechyshynNagasawa (University of Guelph, Guelph, Ontario, Canada) and the methodology developed by Harris (1986) was used to obtain a pure suspension of $P$. cactorum zoospores with some modifications. A circular mesh (Home Hardware, Guelph, Ontario, Canada) with $1-\mathrm{mm}$ holes was placed in a $250-\mathrm{mL}$ conical flask as a solid, nondegradable substrate so that the mycelium could adhere to it during the growth phase. V8 broth was prepared as follows. One gram of $\mathrm{CaCO}_{3}$ was mixed into $100 \mathrm{~mL}$ of $\mathrm{V} 8100 \%$ vegetable juice (Campbell Soup Co., Etobicoke, Ontario, Canada) and then centrifuged at $7974 g_{\mathrm{n}}$ for $10 \mathrm{~min}$. Fifty milliliters of V8 supernatant was added to $950 \mathrm{~mL}$ of
SDDW to make the V8 broth. Clarified V8 agar was made by adding $15 \mathrm{~g}$ of granulated agar to $1 \mathrm{~L}$ of $\mathrm{V} 8$ broth and melted. V8 broth and agar were sterilized at $121{ }^{\circ} \mathrm{C}$ for $20 \mathrm{~min}$. The zoospore concentration was determined with a hemacytometer and diluted to $\approx 10^{5}$ zoospores $/ \mathrm{mL}$. After each chlorine treatment, surviving zoospores were incubated on clarified V8 agar at $25^{\circ} \mathrm{C}$ for 40 to $48 \mathrm{~h}$.

Pythium aphanidermatum was obtained from an infected green bell pepper (Capsicum annuum). To collect the zoospores, a $1-\mathrm{cm}$ long piece of infected green bell pepper root was transferred to $\mathrm{P}_{5} \mathrm{AR}$ agar and incubated under $24 \mathrm{~h}$ of light at $25^{\circ} \mathrm{C}$ for $48 \mathrm{~h} . \mathrm{P}_{5} \mathrm{AR}$ agar, which is selective for members of the family Pythiaceae, contained $20 \mathrm{~g}$ cornmeal agar (Fisher Scientific), $5 \mathrm{mg} \cdot \mathrm{L}^{-1}$ pimaricin, $250 \mathrm{mg} \cdot \mathrm{L}^{-1}$ ampicillin, and $10 \mathrm{mg} \cdot \mathrm{L}^{-1} \mathrm{rifam}-$ picin dissolved in $95 \%$ ethanol. A $0.5-\mathrm{cm}$ diameter plug of $P$. aphanidermatum from the outer edge of the culture was transferred to another $\mathrm{P}_{5} \mathrm{AR}$ plate and incubated under $24 \mathrm{~h}$ of light at $25^{\circ} \mathrm{C}$ for another $48 \mathrm{~h}$. This step was repeated twice to obtain a purified culture of $P$. aphanidermatum. From the outer edge of the culture, another $0.5-\mathrm{cm}$ diameter plug of $P$. aphanidermatum was transferred to V8 agar and incubated under $24 \mathrm{~h}$ of light at $25^{\circ} \mathrm{C}$ for $48 \mathrm{~h}$. V8 agar media used for $P$. aphanidermatum (described subsequently) was prepared differently from V8 agar media used for P. cactorum. The V8 agar plate was cut into six equal strips and three alternating strips were placed in an empty sterile $100 \times 15$-mm petri dish. Twenty milliliters of SDDW was added to each petri dish and incubated under $24 \mathrm{~h}$ of light at $25^{\circ} \mathrm{C}$ for $48 \mathrm{~h}$. The SDDW was decanted from the petri dishes, and another $20 \mathrm{~mL}$ of SDDW was added to each petri dish. Petri dishes were then incubated at room temperature with light for $4 \mathrm{~h}$. The water suspension containing the zoospores from each petri dish was filtered through a sterile metal strainer with a 1-mm mesh to remove large hyphal fragments. The zoospore concentration was determined with a hemacytometer and diluted to $\approx 10^{4}$ zoospores $/ \mathrm{mL}$. After each chlorine treatment, surviving zoospores were incubated on $\mathrm{P}_{5} \mathrm{AR}$ agar at $25^{\circ} \mathrm{C}$ with $24 \mathrm{~h}$ of light for 20 to $24 \mathrm{~h}$.

V8 agar used for $P$. aphanidermatum was prepared as follows. Three grams of $\mathrm{CaCO}_{3}$ was mixed into $200 \mathrm{~mL}$ of $\mathrm{V} 8100 \%$ vegetable juice (Campbell Soup Co.) and then added to $800 \mathrm{~mL}$ of SDDW with $12 \mathrm{~g}$ of granulated agar (Fisher Scientific). The agar was melted and then sterilized at $121{ }^{\circ} \mathrm{C}$ for 20 min.

A pure isolate of Fusarium oxysporum was incubated on potato dextrose agar (PDA) (Fisher Scientific) at $25^{\circ} \mathrm{C}$ with $12 \mathrm{~h}$ of light and $12 \mathrm{~h}$ of dark for $10 \mathrm{~d}$ to collect conidia. The mycelia was then removed by adding 25 $\mathrm{mL}$ of SDDW and then dislodged with a cell scraper. Two milliliters of the $F$. oxysporum suspension was added to $100 \mathrm{~mL}$ of potato dextrose broth (PDB) (Fisher Scientific) in a $250-\mathrm{mL}$ flask and incubated at $30^{\circ} \mathrm{C}$ for $72 \mathrm{~h}$.
Fifty milliliters of the $100 \mathrm{~mL} F$. oxysporum culture was then subcultured into another $1 \mathrm{~L}$ of PDB in a $2800-\mathrm{mL}$ flask and incubated at $30{ }^{\circ} \mathrm{C}$ for $72 \mathrm{~h}$ to produce and release the conidia. The $F$. oxysporum culture was filtered through two layers of cheesecloth to remove the mycelia. The filtrate was centrifuged at $1464 g_{n}$ with a temperature of $4{ }^{\circ} \mathrm{C}$ for $30 \mathrm{~min}$. The supernatant was decanted and the pellet resuspended in $200 \mathrm{~mL}$ of SDDW. The conidia concentration was determined with a hemacytometer and diluted to $\approx 10^{6}$ conidia $/ \mathrm{mL}$. After each chlorine treatment, surviving conidia were incubated on PDA at $30{ }^{\circ} \mathrm{C}$ for 20 to $26 \mathrm{~h}$.

A pure isolate of Rhizoctonia solani was obtained from Diana Mooij from the Department of Environmental Biology, University of Guelph (Guelph, Ontario, Canada) and incubated on PDA at room temperature for $7 \mathrm{~d}$ to collect the mycelia. Fifty milliliters of PDB in a $125-\mathrm{mL}$ Erlenmeyer flask was inoculated with two 5-mm diameter plugs of 7-d-old $R$. solani grown on PDA and incubated at $30{ }^{\circ} \mathrm{C}$ for $7 \mathrm{~d}$. The PDB was decanted and the two 5-mm plugs were removed from the mycelia mat. The mycelia mat was rinsed with $20 \mathrm{~mL}$ of SDDW and homogenized in a Westinghouse Model WST2024ZE 3 Speed Blender at speed 1 (Maxim-Toastmaster, Lake Forest, IL) for $1 \mathrm{~min}$ with $100 \mathrm{~mL}$ of SDDW. The mycelia concentration was determined with a hemacytometer and diluted to $\approx 10^{4}$ mycelia $/ \mathrm{mL}$. After each chlorine treatment, surviving mycelia were incubated on PDA at $30{ }^{\circ} \mathrm{C}$ for $7 \mathrm{~d}$.

Chlorinated water. A fresh stock solution of free chlorine $\left(69 \mathrm{mg} \cdot \mathrm{L}^{-1}\right)$ was prepared from $4 \%$ to $6 \%$ sodium hypochlorite (Fisher Scientific) with SDDW and adjusted to $\mathrm{pH}$ 6.5 to 7 with hydrochloric acid because chlorine is reported to be the most effective at this $\mathrm{pH}$ range (Frink and Bugbee, 1987). The stock solution was diluted with SDDW to achieve the desired free chlorine treatment concentration (as given subsequently). Initial free chlorine concentrations were measured with a C201 Oakton Colorimeter using the protocol specific to this colorimeter (Oakton Instruments, Vermont Hills, IL).

Treatments. Sporangia, zoospores, conidia, or mycelia of the pathogens were exposed to different initial free chlorine concentrations with SDDW as an untreated control for five contact times $(0.5,1.5,3,6$, and $10 \mathrm{~min})$. P. cactorum and P. aphanidermatum were exposed to $0.3,0.4,0.5,1$, and $2 \mathrm{mg} \cdot \mathrm{L}^{-1}$ of free chlorine. P. infestans was exposed to $0.3,0.4,1,2$, and $3 \mathrm{mg} \cdot \mathrm{L}^{-1}$ of free chlorine. $F$. oxysporum was exposed to 4,8 , 10,12 , and $14 \mathrm{mg} \cdot \mathrm{L}^{-1}$ of free chlorine. $R$. solani was exposed to $5,6,7,10$, and 12 $\mathrm{mg} \cdot \mathrm{L}^{-1}$ of free chlorine.

Each free chlorine treatment was achieved by mixing $90 \mathrm{~mL}$ of chlorinated water with $10 \mathrm{~mL}$ of pathogen suspension. At each contact time, a $1-\mathrm{mL}$ sample was removed from the treatment to obtain a survival curve. The free chlorine reaction was stopped by adding the $1-\mathrm{mL}$ sample to 
$9 \mathrm{~mL}$ of PDB to neutralize the free chlorine. Two more serial dilutions were made immediately into another two $9 \mathrm{~mL}$ of PDB and then an aliquot of $100 \mu \mathrm{L}$ of each dilution was spread onto a $100 \times 15$-mm petri dish containing the pathogen's growth media. Petri dishes were incubated under each pathogen's growth condition as described previously. The colony count method was used to determine the total number of developed survivor colonies under each contact time and was recorded. The survivors were represented by the number of cfu in a 1-mL cell suspension $(\mathrm{cfu} / \mathrm{mL})$. This was also done for the untreated control with SDDW. Ten milliliters of SDDW was also added to $90 \mathrm{~mL}$ of treatment chlorinated water as a control to monitor if the chlorine concentration would change over time when there were no pathogen propagules present (chlorine control). In addition, as the $1-\mathrm{mL}$ sample was removed from the free chlorine treatment at each contact time, simultaneously another $10 \mathrm{~mL}$ of the free chlorine treatment was removed to determine the free chlorine concentration under each contact time using a colorimeter. Ten milliliters was also removed from the chlorine control at each contact time and measured with a colorimeter to determine the free chlorine concentration under each contact time when there were no pathogen propagules present. A C201 Oakton Colorimeter (Oakton Instruments) was used to measure the free chlorine concentration of chlorine treatment and chlorine control. This test was performed three times for each free chlorine concentration on each pathogen.

Statistical analysis. SAS software version 9.1 (SAS Institute, Cary, NC) was used to perform homogeneity testing to pool the data and to calculate the least squares means and SEs.

\section{Results}

As the initial free chlorine concentration increased, the number of inactivated sporangia of $P$. infestans, zoospores of $P$. cactorum and $P$. aphanidermatum, conidia of $F$. oxysporum, and mycelia of $R$. solani increased. The free chlorine threshold and critical contact time for $P$. infestans sporangia, $P$. cactorum and $P$. aphanidermatum zoospores, $F$. oxysporum conidia, and $R$. solani mycelia were $1,0.3,2,14$, and $12 \mathrm{mg} \cdot \mathrm{L}^{-1}$ of free chlorine for $3,6,3,6$, and $10 \mathrm{~min}$ in double distilled water, respectively (Figs. 1-5).

For each pathogen, the contact times in which the concentration of inactivated propagules became consistent were $0.5 \mathrm{~min}$ for all five initial free chlorine concentrations for $P$. infestans sporangia (Fig. 1); $1.5 \mathrm{~min}$ for 0.3 $\mathrm{mg} \cdot \mathrm{L}^{-1}$ of free chlorine (Fig. 2A) and $0.5 \mathrm{~min}$ for $0.4,0.5,1$, and $2 \mathrm{mg} \cdot \mathrm{L}^{-1}$ of free chlorine (Fig. 2B-E) for $P$. cactorum zoospores; $3 \mathrm{~min}$ for $0.3 \mathrm{mg} \cdot \mathrm{L}^{-1}$ of free chlorine (Fig. $3 \mathrm{~A}$ ) and $0.5 \mathrm{~min}$ for $0.4,0.5,1$, and $2 \mathrm{mg} \cdot \mathrm{L}^{-1}$ of free chlorine (Fig. 3B-E) for P. aphanidermatum zoospores; and $1.5 \mathrm{~min}$ for 4,12 , and 14 $\mathrm{mg} \cdot \mathrm{L}^{-1}$ of free chlorine (Fig. 4A, D, and E), 3 min for $8 \mathrm{mg} \cdot \mathrm{L}^{-1}$ of free chlorine (Fig. 4B), and $6 \mathrm{~min}$ for $10 \mathrm{mg} \cdot \mathrm{L}^{-1}$ of free chlorine (Fig. 4C) for $F$. oxysporum conidia. Unlike $P$. infestans, $P$. cactorum, $P$. aphanidermatum, and $F$. oxysporum, the concentration of inactivated propagules of $R$. solani only became consistent at $12 \mathrm{mg} \cdot \mathrm{L}^{-1}$ of free chlorine after 6 min of contact time (Fig. 5E).

The free chlorine concentration in each treatment also decreased over time by contact with the propagules of all five pathogens (Figs. 1-5) compared with the chlorine control, which did not decrease in free chlorine concentration over time (data not shown). The free chlorine concentration, however, did not decrease as rapidly by contact with $P$. cactorum zoospores (Fig. 2), F. oxysporum conidia (Fig. 4), and R. solani mycelia (Fig. 5 ) as the free chlorine that came in contact with $P$. infestans or $P$. aphanidermatum.

\section{Discussion}

The sporangia of Phytophthora infestans, the zoospores of Phytophthora cactorum and Pythium aphanidermatum, the conidia of Fusarium oxysporum, and the mycelia of Rhizoctonia solani in this study were killed by free chlorine at different initial concentrations. Previous investigations demonstrate that chlorine sensitivity can differ with genus, species, pathovar, and/or propagules (Hong et al., 2003). Chauret et al. (2001) reported that bacterial spores of Bacillus subtilis and Clostridium sporogenes are more sensitive to chlorine than Clostridium parvum oocysts. Blaser et al. (1986) reported that three different strains of Campylobacter jejuni were killed with $0.1 \mathrm{mg} \cdot \mathrm{L}^{-1}$ of free chlorine at a contact time of $5 \mathrm{~min}$. Thompson (1965) reported Erwinia carotovora subsp. zeae Sabet was killed with $1 \mathrm{mg} \cdot \mathrm{L}^{-1}$ of free chlorine, but Erwinia chrysanthemi Burkholder et al. and E. carotovora subsp. carotovora (Jones) Bergey were less sensitive to chlorine, which survived at $10 \mathrm{mg} \cdot \mathrm{L}^{-1}$ (Lacy et al., 1981). Differences in the sensitivity of different pathogens and propagules to chlorine support our findings that the pathogens and propagules in this study exhibited differences in sensitivity to chlorine.

The five pathogens in this study were killed at different critical contact times. Literature supports that pathogen sensitivity to chlorine varies with contact time (Copes et al., 2001; Datnoff et al., 1987; Johnson et al., 1997; Segall, 1968). Korich et al. (1990) reported that $80 \mathrm{mg} \cdot \mathrm{L}^{-1}$ applied for $90 \mathrm{~min}$ was required to inactivate $90 \%$ of Cryptosporidium parvum oocysts. Datnoff et al. (1987) reported that resting spores of Plasmodiophora brassicae were killed after treatment with $2 \mathrm{mg} \cdot \mathrm{L}^{-1}$ for at least $5 \mathrm{~min}$, and Berman and Hoff (1984) reported that 0.5 $\mathrm{mg} \cdot \mathrm{L}^{-1}$ of chlorine inactivated simian rotavirus SA11 within $4 \mathrm{~min}$.

Initial free chlorine concentrations required to kill $P$. infestans, $P$. cactorum, and $P$. aphanidermatum were much lower than that of $F$. oxysporum and $R$. solani. Literature reports that the order of fungal propagule sensitivity (most to least) to fungicides is cysts, zoospores, sporangia, hyphae, and conidia (Fernández-Torres et al., 2003; Harnik and Garbelotto, 2007; Stein and Kirk, 2003). These findings suggest that sporangia and zoospores of Pythiaceae pathogens are more sensitive to chemical treatment than hyphae and conidia.

Research by Hong et al. (2003) reported that free chlorine concentrations ranging from 0.25 to $2 \mathrm{mg} \cdot \mathrm{L}^{-1}$ were able to kill the zoospores of Phytophthora nicotianae, $P$. capsici, P. cinnamomi, P. citricola, $P$. citrophthora, $P$. cryptogea, and $P$. megasperma, which supports our results that low free chlorine concentrations can kill $P$. infestans, $P$. cactorum, and $P$. aphanidermatum.

Both chemical and nonchemical methods of control for Fusarium and Rhizoctonia only reduce infection and do not fully control the spread of these pathogens (Asaka and Shoda, 1996; Howell et al., 2000; Reuveni et al., 2002; Szczech and Shoda, 2006), which demonstrate how difficult it is to control these pathogens. This supports our results that $F$. oxysporum and $R$. solani are resilient to chlorine and require higher free chlorine concentrations to kill them. This is further supported by Igura et al. (2004) who reported that water containing ozone concentrations up to $1 \mathrm{mg} \cdot \mathrm{L}^{-1}$ was only able to reduce the conidia of $F$. oxysporum by a $10^{4}$ order from a concentration of $10^{8} \mathrm{cfu} / \mathrm{mL}$. Ozone is considered to be a stronger oxidizer than chlorine (Graham, 1997; Tyrrell et al., 1995), but the inability of ozone to completely kill $F$. oxysporum, as shown by Igura et al. (2004), demonstrates the resilience of $F$. oxysporum to chemical treatment and supports the necessary use of a high initial free chlorine concentration to kill $F$. oxysporum.

As the initial free chlorine concentration increased, the number of propagules that were killed increased for all five plant pathogens. This may be because as the initial concentration of free chlorine increased, there was more free chlorine available to inactivate the pathogen, therefore inactivating more propagules. The same phenomenon was also observed by Hong et al. (2003) in which the number of inactivated sporangia, zoospores, and mycelia of Phytophthora spp. increased with increasing free chlorine concentration. Igura et al. (2004) also reported that the number of inactivated conidia increased with increasing ozone concentrations.

Free chlorine concentration rapidly decreased by contact with $P$. infestans and $P$. aphanidermatum. Because free chlorine is oxidized by organic matter and other oxidizable substances (White, 1992), free chlorine concentrations decreased as a result of the oxidation of pathogen propagules. This phenomenon was also observed by other researchers who have used chlorine or other oxidizing compound to disinfect pathogens (Hong et al., 2003; Igura et al., 2004); however, the free chlorine concentrations did not decrease as rapidly for $P$. cactorum, $F$. oxysporum, and $R$. solani. Because conidia 

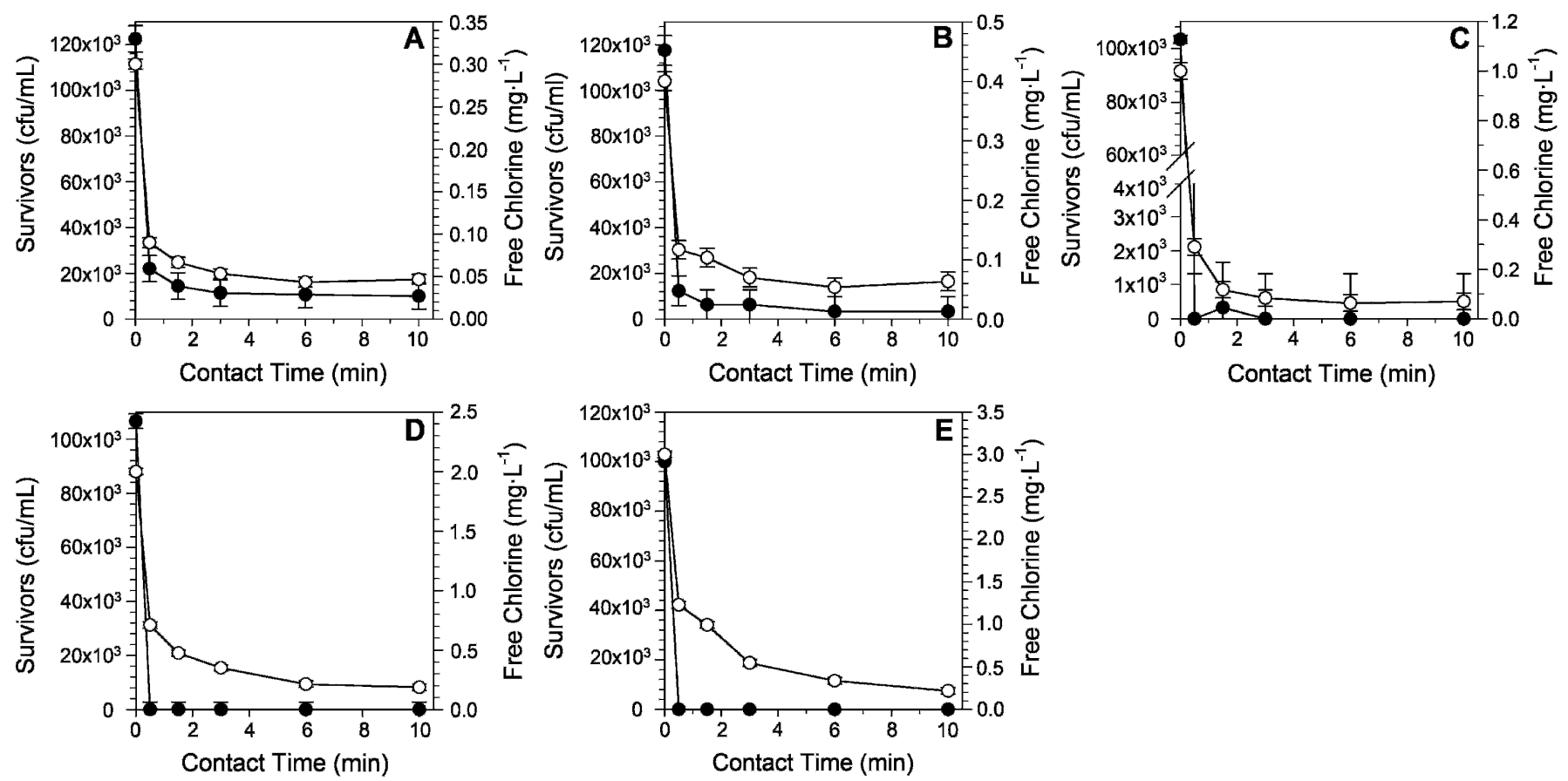

Fig. 1. Relationships between survivors of Phytophthora infestans sporangia $(\mathrm{cfu} / \mathrm{mL})$ and free chlorine concentration $\left(\mathrm{mg} \cdot \mathrm{L}^{-1}\right)$ after treatment with initial free chlorine concentrations $0.3(\mathbf{A}), 0.4(\mathbf{B}), 1.0(\mathbf{C}), 2.0(\mathbf{D})$, and $3.0(\mathbf{E}) \mathrm{mg} \cdot \mathrm{L}^{-1}$. The solid and open symbols indicate the survivors $(\mathrm{cfu} / \mathrm{mL})$ and the free chlorine concentrations $\left(\mathrm{mg} \cdot \mathrm{L}^{-1}\right)$, respectively. Each datum point is the mean of three replicates \pm the SE of the mean.

and mycelia have thicker cell walls than zoospores and sporangia (Alexopoulos et al., 1996; Carlile et al., 2004; Erwin et al., 1983; Fernández-Torres et al., 2003), it may require more time for free chlorine to oxidize conidia and mycelia. This would result in a slower decrease in free chlorine concentration over time. However, this does not explain why free chlorine concentrations did not decrease rapidly when it came into contact with $P$. cactorum zoospores. Because $P$. cactorum zoospores have the lowest free chlorine threshold of $0.3 \mathrm{mg} \cdot \mathrm{L}^{-1}$, only a minimal concentration of free chlorine was required to kill the zoospores. Therefore, not as much free chlorine would be needed to kill $P$. cactorum zoospores and would not decrease as rapidly as free chlorine oxidized by $P$. infestans sporangia and $P$. aphanidermatum zoospores.
For P. infestans, P. cactorum, P. aphanidermatum, and $F$. oxysporum, the concentration of inactivated propagules eventually became consistent during chlorine treatment. The same phenomenon was also observed in research conducted by Hong et al. (2003) with chlorine and Igura et al. (2004) with ozone. However, this was only observed in $R$. solani treated with $12 \mathrm{mg} \cdot \mathrm{L}^{-1}$ of free chlorine (Fig. 5E). The concentration
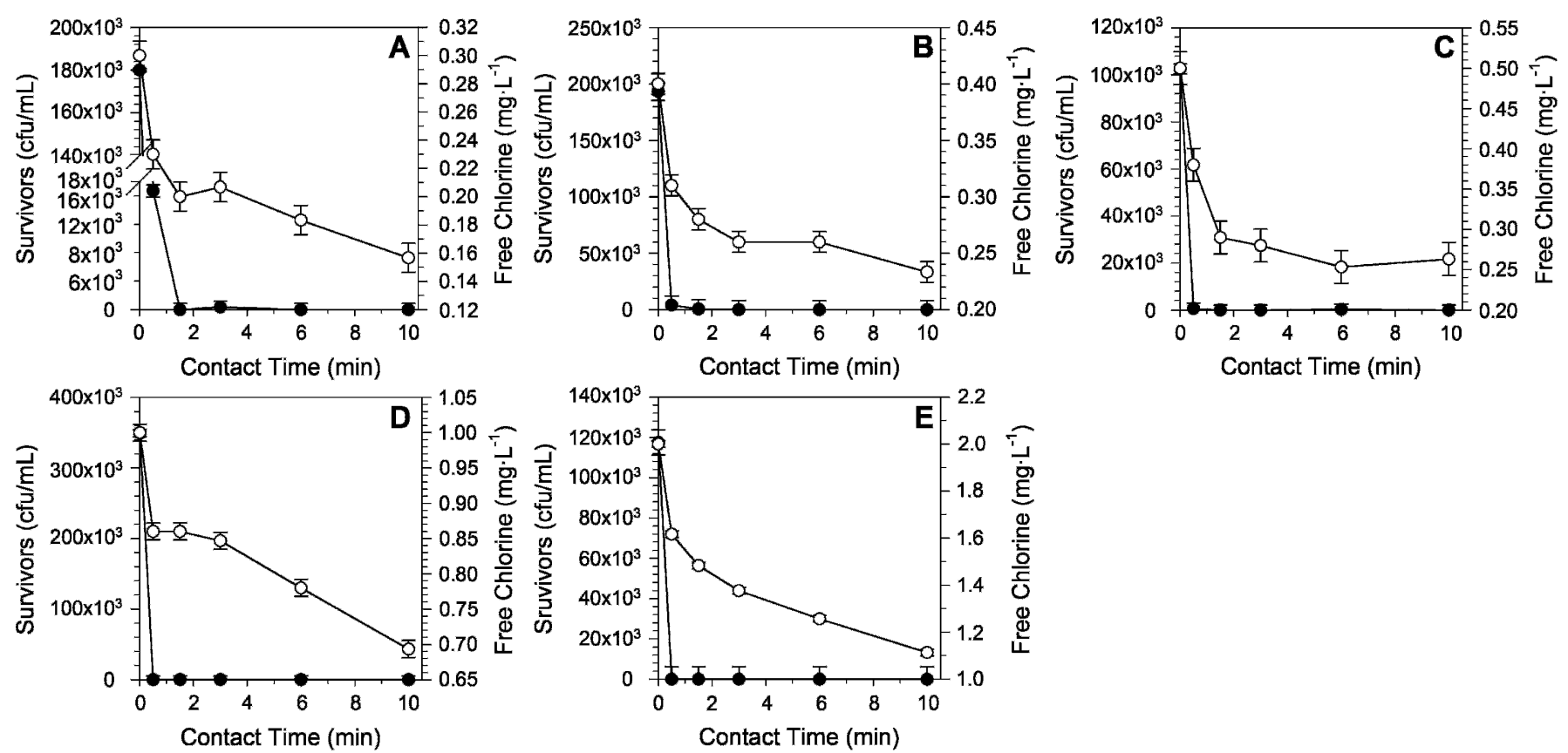

Fig. 2. Relationships between survivors of Phytophthora cactorum zoospores $(\mathrm{cfu} / \mathrm{mL})$ and free chlorine concentration $\left(\mathrm{mg} \cdot \mathrm{L}^{-1}\right)$ after treatment with initial free chlorine concentrations $0.3(\mathbf{A}), 0.4(\mathbf{B}), 0.5(\mathbf{C}), 1.0(\mathbf{D})$, and $2.0(\mathbf{E}) \mathrm{mg} \cdot \mathrm{L}^{-1}$. The solid and open symbols indicate the survivors $(\mathrm{cfu} / \mathrm{mL})$ and the free chlorine concentrations $\left(\mathrm{mg} \cdot \mathrm{L}^{-1}\right)$, respectively. Each datum point is the mean of three replicates \pm the SE of the mean. 

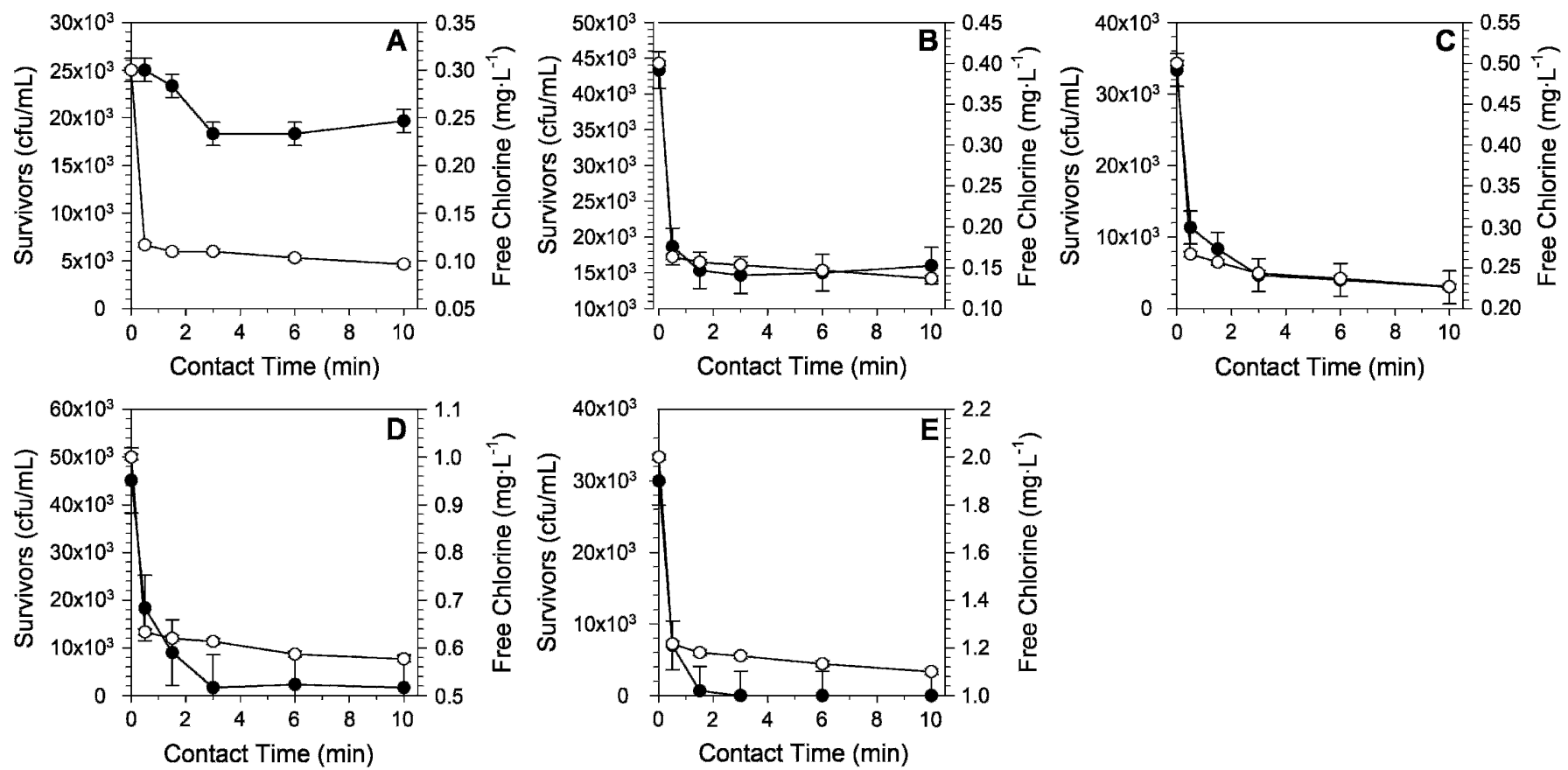

Fig. 3. Relationships between survivors of Pythium aphanidermatum zoospores $(\mathrm{cfu} / \mathrm{mL})$ and free chlorine concentration $\left(\mathrm{mg} \cdot \mathrm{L}^{-1}\right)$ after treatment with initial free chlorine concentrations $0.3(\mathbf{A}), 0.4(\mathbf{B}), 0.5(\mathbf{C}), 1.0(\mathbf{D})$, and $2.0(\mathbf{E}) \mathrm{mg} \cdot \mathrm{L}^{-1}$. The solid and open symbols indicate the survivors $(\mathrm{cfu} / \mathrm{mL})$ and the free chlorine concentrations $\left(\mathrm{mg} \cdot \mathrm{L}^{-1}\right)$, respectively. Each datum point is the mean of three replicates \pm the $\mathrm{SE}$ of the mean.

of inactivated mycelia hardly became consistent for free chlorine treatments at 5,6 , 7, and $10 \mathrm{mg} \cdot \mathrm{L}^{-1}$ (Fig. 5A-D). This may be because the free chlorine was constantly inactivating the mycelia, therefore never reaching a consistent concentration of inactivated mycelia within the 10-min interval the mycelia were exposed to the chlorine.
Because free chlorine is consumed as it is oxidizing the pathogen propagule over time, the free chlorine thresholds reported are the initial free chlorine concentrations in which pathogen propagules were treated and represent the maximum free chlorine concentrations at which pathogen propagules can be killed. The critical contact times are the times in which pathogen propagules were no longer detected without keeping the free chlorine concentration constant at the initial free chlorine concentration. The free chlorine threshold and critical contact time of $P$. infestans, $P$. cactorum, $P$. aphanidermatum, $F$. oxysporum, and $R$. solani were $1,0.3,2$, 14 , and $12 \mathrm{mg} \cdot \mathrm{L}^{-1}$ for $3,6,3,6$, and $10 \mathrm{~min}$ in double distilled water, respectively. Because irrigation water is loaded with organic matter,
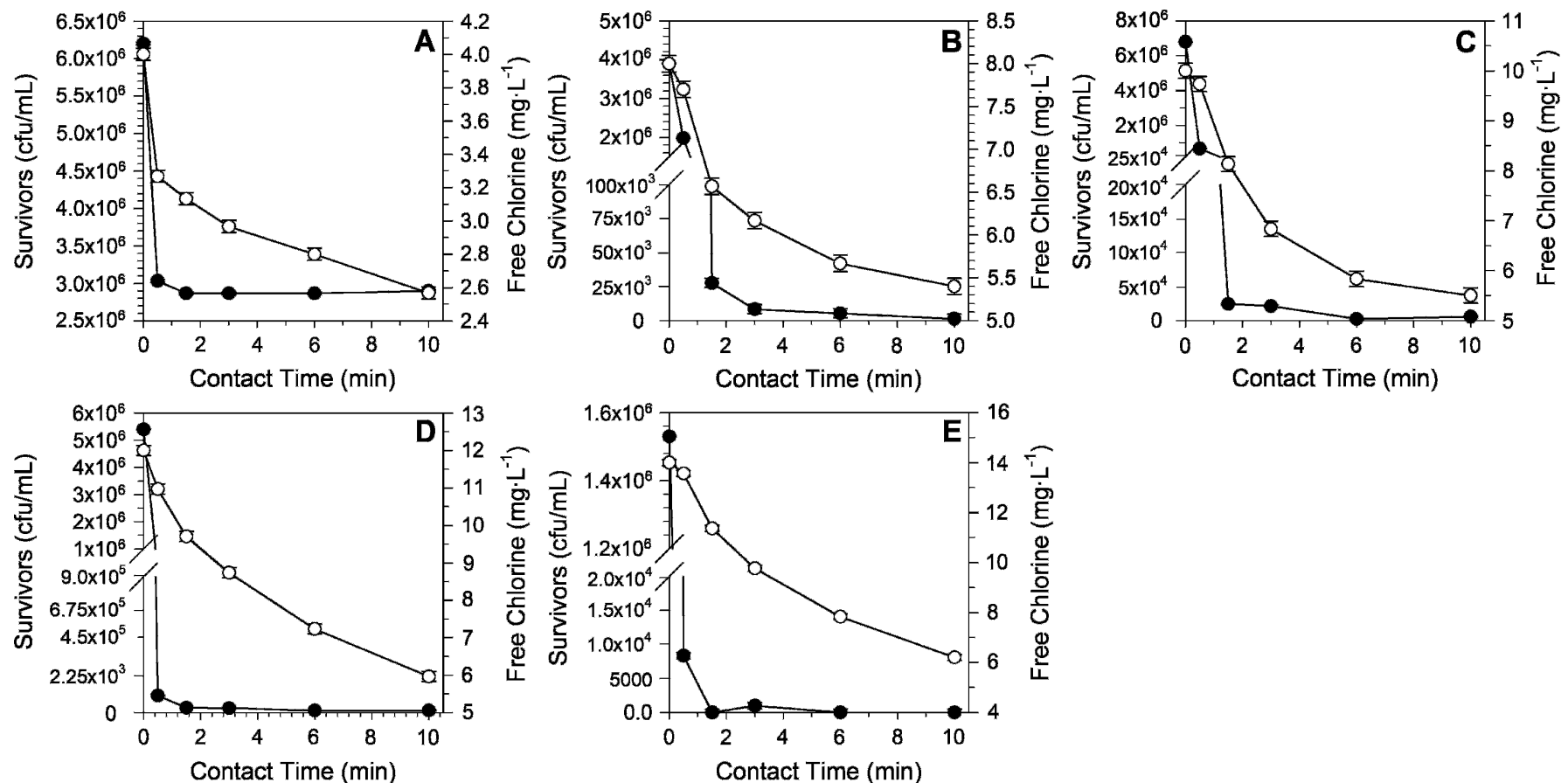

Fig. 4. Relationships between survivors of Fusarium oxysporum conidia (cfu/mL) and free chlorine concentration $\left(\mathrm{mg} \cdot \mathrm{L}^{-1}\right)$ after treatment with initial free chlorine concentrations $4.0(\mathbf{A}), 8.0(\mathbf{B}), 10.0(\mathbf{C}), 12.0(\mathbf{D})$, and $14.0(\mathbf{E}) \mathrm{mg} \cdot \mathrm{L}^{-1}$. The solid and open symbols indicate the survivors $(\mathrm{cfu} / \mathrm{mL})$ and the free chlorine concentrations $\left(\mathrm{mg} \cdot \mathrm{L}^{-1}\right)$, respectively. Each datum point is the mean of three replicates \pm the SE of the mean. 

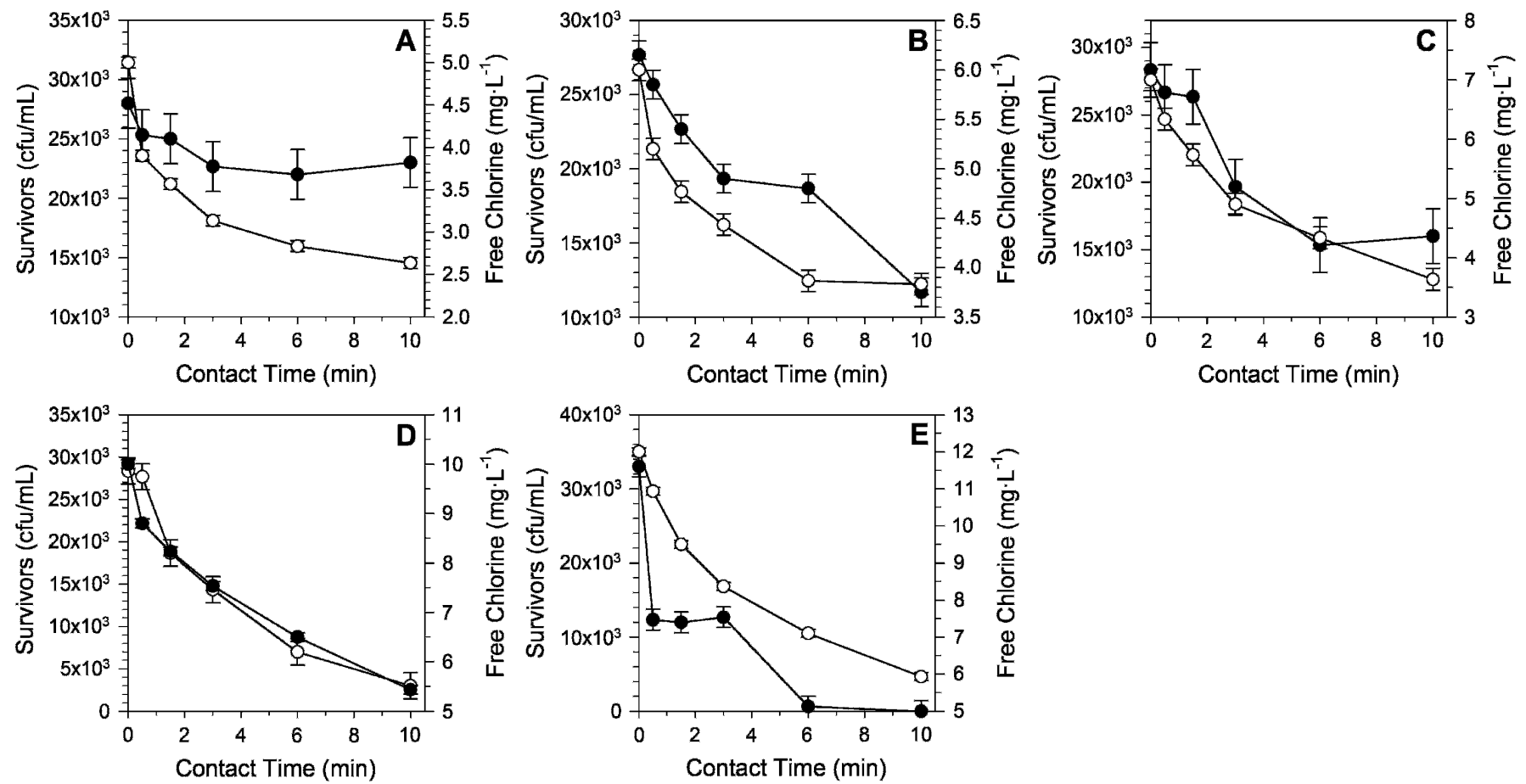

Fig. 5. Relationships between survivors of Rhizoctonia solani mycelia $(\mathrm{cfu} / \mathrm{mL})$ and free chlorine concentration $\left(\mathrm{mg} \cdot \mathrm{L}^{-1}\right)$ after treatment with initial free chlorine concentrations $5.0(\mathbf{A}), 6.0(\mathbf{B}), 7.0(\mathbf{C}), 10.0(\mathbf{D})$, and $12.0(\mathbf{E}) \mathrm{mg} \cdot \mathrm{L}^{-1}$. The solid and open symbols indicate the survivors (cfu/mL) and the free chlorine concentrations $\left(\mathrm{mg} \cdot \mathrm{L}^{-1}\right)$, respectively. Each datum point is the mean of three replicates \pm the SE of the mean.

the free chlorine thresholds that we have reported would be kept constant during the contact time required for treatment once the chlorine demand of the irrigation water has been satisfied. However, contact time may decrease at each pathogen's free chlorine threshold because the free chlorine concentration of the irrigation water would be kept constant, thus reducing the amount of time required to kill the pathogen.

If recycled irrigation water were maintained at a free chlorine concentration of 14 $\mathrm{mg} \cdot \mathrm{L}^{-1}$ of free chlorine for $6 \mathrm{~min}$, it may control the spread of the five common plant pathogens. However, our previous research (Cayanan et al., 2008) found that the threshold of chlorine concentration, which would not adversely affect the growth or appearance of plants, was less than $2.5 \mathrm{mg} \cdot \mathrm{L}^{-1}$. Recycled irrigation water with $14 \mathrm{mg} \cdot \mathrm{L}^{-1}$ of free chlorine is greater than the free chlorine threshold for the nursery species studied.

Because previous studies have indicated that Pythiaceae pathogens are the most common, destructive, and significant contaminants in irrigation systems to cause disease in crops (Alexopoulos et al., 1996; Bush, 2002; Errampalli et al., 2006; Erwin and Ribeiro, 1996; Schnitzler, 2003; Shokes and McCarter., 1979), it would be in the best interest of nursery and greenhouse growers to design their chlorinated irrigation systems to target Pythiaceae pathogens, which would only require irrigation water to maintain a free chlorine concentration of $2 \mathrm{mg} \cdot \mathrm{L}^{-1}$ to kill the pathogens. This would allow growers to control the spread of Pythiaceae pathogens and not cause any negative effects on plants if irrigated with chlorinated water. If growers find that $F$. oxysporum and $R$. solani are a common problem in their nursery or greenhouse, then chlorinated irrigation systems may be designed to target these pathogens with a constant free chlorine concentration of $14 \mathrm{mg} \cdot \mathrm{L}^{-1}$, but the system must be designed to remove chlorine from the irrigation water before watering the plants. Removal of chlorine can be done by aerating, use of active carbon, or chemical treatment with sodium dioxide, sodium sulfite, or sodium metabisulfite (White, 1992). Another option for growers that need to target all five pathogens, but do not want to design their system to remove chlorine from the irrigation water, is to maintain irrigation water at a free chlorine concentration of $2 \mathrm{mg} \cdot \mathrm{L}^{-1}$ to kill Pythiaceae pathogens, but the contact time must be increased to allow a sufficient contact time to kill $F$. oxysporum and $R$. solani. However, further research is required to determine what contact time would be sufficient to kill $F$. oxysporum and $R$. solani at $2 \mathrm{mg} \cdot \mathrm{L}^{-1}$ of free chlorine.

\section{Literature Cited}

Alexopoulos, C.J., C.W. Mims, and M. Blackwell. 1996. Introductory mycology. 4th Ed. Wiley, New York, NY.

Asaka, O. and M. Shoda. 1996. Biocontrol of Rhizoctonia solani damping-off of tomato with Bacillus subtilis RB14. Appl. Environ. Microbiol. 62:4081-4085.

Ben-Yephet, Y. and E.B. Nelson. 1999. Differential suppression of damping-off caused by Pythium aphanidermatum, P. irregulare and $P$. myriotylum in composts at different temperatures. Plant Dis. 83:356-360.

Berman, D. and J.C. Hoff. 1984. Inactivation of simian rotavirus SA11 by chlorine, chlorine dioxide, and monochloramine. Appl. Environ. Microbiol. 48:317-323.

Blaser, M.J., P.F. Smith, W.L. Wang, and J.C. Hoff. 1986. Inactivation of Campylobacter jejuni by chlorine and monochloramine. Appl. Environ. Microbiol. 51:307-311.

Bush, E.A. 2002. Characterization of Phytophthora species in recycled irrigation water at a container nursery in southwestern Virginia. Va. Polytechnic Inst. State Univ., Va. MSc Diss.

Bush, E.A., C. Hong, and E.L. Stromberg. 2003. Fluctuations of Phytophthora and Pythium spp. in components of a recycling irrigation system. Plant Dis. 87:1500-1506.

Carlile, M.J., S.C. Watkinson, and G.W. Gooday. 2004. The fungi. 2nd Ed. Elsevier Ltd., London, UK.

Cayanan, D.F., Y. Zheng, C. Chong, P. Zhang, T. Graham, J. Llewellyn, and M. Dixon. 2008. Sensitivity of five container-grown nursery species to chlorine in overhead irrigation water. HortScience 43:1882-1887.

Chauret, C.P., C.Z. Radziminski, M. Lepuil, R Creason, and R.C. Andrews. 2001. Chlorine dioxide inactivation of Cryptosporidium parvum oocysts and bacterial spore indicators. Appl. Environ. Microbiol. 67:2993-3001.

Copes, W.E., G.A. Chastaganer, and R.L. Hummel. 2001. Influence of select inorganic elements and $\mathrm{pH}$ on the fungicidal activity of chlorine dioxide in water. Proc. South Nursery Assoc. Res. Conf. 46:284-286.

Datnoff, L.E., R.K. Droll, and G.H. Lacy. 1987. Efficacy of chlorine for decontaminating water infested with resting spores of Plasmodiophora brassicae. Plant Dis. 71:734-736.

Ehret, D.L., B. Alsanius, W. Wohanka, J.G. Menzies, and R. Utkhede. 2001. Disinfestation of recirculating nutrient solutions in greenhouse horticulture. Agronomie 21:323-339.

Errampalli, D., R.D. Peters, K. MacIsaac, D. Darrach, and P. Boswall. 2006. Effect of a combination of chlorine dioxide and thiophanate-methyl 
pre-planting seed tuber treatment on the control of black scurf of potatoes. Crop Prot. 25:12311237.

Erwin, D.C., S. Bartnicki-Garcia, and P.H. Tsao. 1983. Phytophthora: Its biology, taxonomy, ecology, and pathology. American Phytopathological Society, St. Paul, MN.

Erwin, D.C. and O.K. Ribeiro. 1996. Phytophthora diseases worldwide. APS Press, St. Paul, MN.

Faulkner, L.R. and W.J. Bolander. 1966. Occurrence and largen nematode populations in irrigation canals of south central Washington. Nematologia 12:591-600.

Fernández-Torres, B., L. Inza, and J. Guarro. 2003. Comparison of in vitro antifungal susceptibilities of conidia and hyphae of dermatophytes with thick-wall macroconidia. Antimicrob. Agents Chemother. 47:3371-3372.

Frink, C.R. and G.J. Bugbee. 1987. Response of potted plants and vegetable seedlings to chlorinated water. HortScience 22:581-583.

Graham, D. 1997. Use of ozone for food processing. Food Technol. 51:72-73.

Griffini, O., M.L. Bao, D. Burrini, D. Santianni, C. Barbieri, and F. Pantani. 1999. Removal of pesticides during the drinking water treatment process at Florence water supply, Italy. AquaColchester 48:177-185.

Harnik, R.Y. and M. Garbelotto. 2007. Effect of chemicals on hyphal growth, sporangia production and zoospore germination of Phytophthora ramorum. Depart. Environ. Sci., Univ. of Berkeley. 20 Dec. 2007. <http://nature.berkeley. edu.cerberus.lib.uoguelph.ca/garbelotto/down loads/posters/sod2005\%20tami.pdf $>$.

Harris, D.C. 1986. Methods for preparing, estimating and diluting suspensions of Phytophthora cactorum zoospores. Trans. Br. Mycol. Soc. $86: 482-486$.

Havard, P. 2003. Farm irrigation water safety initiative final report Apr. 2003. Horticulture N.S., N.S. Agr. College.

Hong, C.X. and G.W. Moorman. 2005. Plant pathogens in irrigation water: Challenges and opportunities. Crit. Rev. Plant Sci. 24:189-208.

Hong, C.X., R.A. Richardson, P. Kong, and E.A. Bush. 2003. Efficacy of chlorine on multiple species of Phytophthora in recycled nursery irrigation water. Plant Dis. 87:1183-1189.

Howell, C.R., L.E. Hanson, R.D. Stipanovic, and L.S. Puckhaber. 2000. Induction of terpenoid synthesis in cotton roots and control of Rhizoctonia solani by seed treatment with Trichoderma virens. Phytopathol. 90:248-252.

Igura, N., M. Fujii, M. Shimoda, and I. Hayakawa. 2004. Research note: Inactivation efficiency of ozonated water for Fusarium oxysporum con- idia under hydroponic greenhouse conditions. Ozone Sci. Eng. 26:517-521.

Johnson, C.H., E.W. Rice, and D.J. Reasoner. 1997. Inactivation of Helicobacter pylori by chlorination. Appl. Environ. Microbiol. 63: 4969-4970.

Johnson, S.B. and S.S. Leach. 2006. Rhizoctonia diseases on potatoes. Univ. of Maine, Orono, ME. Bul. 2273.

Koenig, R. 1986. Plant viruses in rivers and lakes. Adv. Virus Res. 31:321-333.

Korich, D.G., J.R. Mead, M.S. Madore, N.A. Sinclair, and C.R. Sterling. 1990. Effects of ozone, chlorine dioxide, chlorine, and monochloramine on Cryptosporidium parvum oocyst viability. Appl. Environ. Microbiol. 56:1423-1428.

Kuhajek, J.M., S.N. Jeffers, M. Slattery, and D.E Wedge. 2003. A rapid microbioassay for discovery of novel fungicides for Phytophthora spp. Phytopathol. 93:46-53.

Lacy, G.H., R.C. Lambe, and C.M. Berg. 1981. Iris soft rot caused by Erwinia chrysanthemi associated with overhead irrigation and its control by chlorination. Combined Proc. Int. Plant Propagators' Soc. 31:624-634.

Le Dantec, C., J.P. Duguet, A. Montiel, N. Dumoutier, S. Dubrou, and V. Vincent. 2002. Chlorine disinfection of atypical mycobacteria isolated from a water distribution system. Appl. Environ. Microbiol. 68:1025-1032.

Lin, Y.S., J.E. Stout, V.L. Yu, and R.D. Vidic. 1998. Disinfection of water distribution systems for Legionella. Semin. Respir. Infect. 13:147-159.

Morganti, L. 2002. Sodium hypochlorite generation for household water disinfection: A case study in Nepal. Mass. Inst. Technol., MA. MsC Diss.

Newman, S.E. 2004. Disinfecting irrigation water for disease management: Society of American Florists 20th Annual Conference on Pest Management on Ornamentals, San Jose, CA, 20-22 Feb.

Poncet, C., M. Offroy, G. Bonnet, and R. Brun. 2001. Disinfection of recycling water in rose cultures. Acta Hort. 547:121-126.

Reuveni, R., M. Raviv, A. Krasnovsky, L. Freiman, S. Medina, A. Bar, and D. Orion. 2002. Compost induces protection against Fusarium oxysporum in sweet basil. Crop Prot. 21:583-587.

Richard, S., Y. Zheng, and M. Dixon. 2006. To recycle or not to recycle? Greenhouse Canada December:22-24.

Rutala, W.A. and D.J. Weber. 1997. Uses of inorganic hypochlorite (bleach) in health-care facilities. Clin. Microbiol. Rev. 10:597-610.

Ryu, J. and L.R. Beuchat. 2005. Biofilm formation by Escherichia coli O157:H7 on stainless steel:
Effect of exopolysaccharide and curlii production on its resistance to chlorine. Appl. Environ. Microbiol. 71:247-254.

Sanders, P.L., W.J. Houser, P.J. Parish, and H.J. Cole. 1985. Reduced-rate fungicide mixtures to delay fungicide resistance and to control selected turfgrass diseases. Plant Dis. 69:939943.

Schnitzler, W.H. 2003. Pest and disease management of soilless culture, p. 191-203. In: Nichols, M.A. (ed.). South pacific soilless culture conference. International Society for Horticultural Science, Technische Universität München 85350 Freising-Weihenstephan, Germany.

Schoene, G., T. Yeager, and D. Haman. 2006. Survey of container nursery irrigation practices in west-central Florida: An educational opportunity. HortTechnology 16:682-685.

Segall, R.H. 1968. Fungicidal effectiveness of chlorine as influenced by concentration, temperature, $\mathrm{pH}$, and spore exposure time. Phytopathol. 58:1412-1414.

Shokes, F.M. and S.M. McCarter. 1979. Occurrence, dissemination, and survival of plant pathogens in surface irrigation ponds in southern Georgia. Phytopathol. 69:510-516.

Skimina, C.A. 1992. Recycling water, nutrients, and waste in the nursery industry. HortScience 27:968-971.

Stein, J.M. and W.W. Kirk. 2003. Variations in the sensitivity of Phytophthora infestans isolates from different genetic backgrounds to dimethomorph. Plant Dis. 87:1283-1289.

Szczech, M. and M. Shoda. 2006. The effect of mode of application of Bacillus subtilis RB14$\mathrm{C}$ on its efficacy as a biocontrol agent against Rhizoctonia solani. J. Phytopathol. 154:370377.

Taylor, R.G., J.O. Falkinham, III, C.D. Norton, and M.W. LeChevallier. 2000. Chlorine, chloramine, chlorine dioxide, and ozone susceptibility of Mycobacterium avium. Appl. Environ. Microbiol. 66:1702-1705.

Thompson, D.L. 1965. Control of bacterial stalk rot of corn by chlorination of water in sprinkler irrigation. Crop Sci. 5:369-370.

Thomson, S.V. and R.M. Allen. 1974. Occurrence of Phytophthora species and other potential plant pathogens in recycled irrigation water. Plant Dis. Rep. 58:945-949.

Tyrrell, S.A., S.R. Rippey, and W.D. Watkins. 1995. Inactivation of bacterial and viral indicators in secondary sewage effluents, using chlorine and ozone. Water Res. 29:2483-2490.

White, G.C. 1992. The handbook of chlorination and alternative disinfectants. 3rd Ed. Van Nostrand Reinhold, New York, NY. 